\title{
Synthesis of ustalic acid, an inhibitor of $\mathrm{Na}^{+}, \mathrm{K}^{+}$-ATPase
}

\author{
Ichiro Hayakawa, Hidekazu Watanabe and Hideo Kigoshi ${ }^{*}$ \\ Department of Chemistry, Graduate School of Pure and Applied Sciences, and Center for Tsukuba Advanced Research Alliance, \\ University of Tsukuba, Tennodai, Tsukuba 305-8571, Japan
}

Abstract- Ustalic acid, an inhibitor of $\mathrm{Na}^{+}, \mathrm{K}^{+}$-ATPase isolated from a poisonous mushroom, was synthesized in 8 steps using the Suzuki-Miyaura coupling and oxidation of methylene acetal as key steps. (C) 2008 Elsevier Science. All rights reserved

\section{Introduction}

Ustalic acid (1) was isolated from a poisonous mushroom, Tricholoma ustale (Kakishimeji in Japanese) by Kawagishi et al. in 2002 (Fig. 1). ${ }^{1}$ Ustalic acid (1) inhibited $\mathrm{Na}^{+}, \mathrm{K}^{+}$-ATPase; $\mathrm{IC}_{50}$ values of ustalic acid (1) against the commercially available enzyme purified from porcine cerebral cortex and the crude enzyme from mouse intestinal mucosal cells were 5.2 and $0.77 \mathrm{mM}$, respectively. In 2006, Nishikawa et al. first achieved the total synthesis of ustalic acid dimethyl ester (2). ${ }^{2}$ We planned an efficient synthesis of ustalic acid (1), which will provide a practical supply for further biological studies. We report here the first synthesis of ustalic acid (1) in 8 steps using Suzuki-Miyaura coupling $^{3}$ as a key step. Recently, Takahashi et al. have reported the total synthesis of a similar compound vialinin A, by a similar cross-coupling strategy. ${ }^{4}$

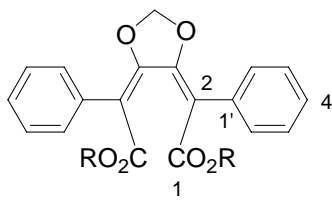

$\mathrm{R}=\mathrm{H}$; ustalic acid (1)

$\mathrm{R}=\mathrm{Me}(2)$

Figure 1. Structures of ustalic acid (1) and derivative.

\section{Results and discussions}

Our synthetic plan of ustalic acid (1) is shown in Scheme 1. Our synthetic route to ustalic acid (1) involved the Suzuki-Miyaura coupling ${ }^{3}$ at $\mathrm{C}-2-\mathrm{C}-1$ '. We therefore synthesized organoboron compound 5 .

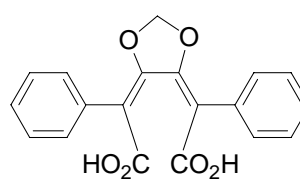

ustalic acid (1)<smiles>[R9]c1c(O)c(-c2ccccc2)c2c(c1-c1ccccc1)OCO2</smiles>

4

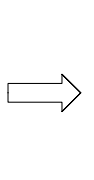

phlebiarubrone (3)

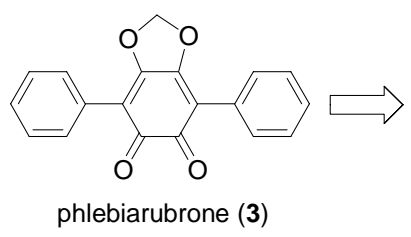<smiles>C=CC</smiles><smiles>[R]OB([R2])c1c([R2])c([R2])c(B([R])[R])c2c1OCO2</smiles>

\footnotetext{
*Corresponding author. : +81 29853 4313; e-mail: kigoshi@chem.tsukuba.ac.jp.
} 
Synthesis of the ustalic acid (1) started from commercially available sesamol (Scheme 2). Sesamol was transformed into catechol 7,5 and the hydroxyl group of 7 was then protected as an acetonide. The introduction of two boronic acid moieties into 8 was accomplished through a double lithiation by using $n$-BuLi and TMEDA at $-78^{\circ} \mathrm{C}$ and trapping with $\mathrm{B}(\mathrm{OMe})_{3}$ to give diboronic acid $\mathbf{9}$ and monoboronic acid $\mathbf{1 0}$.

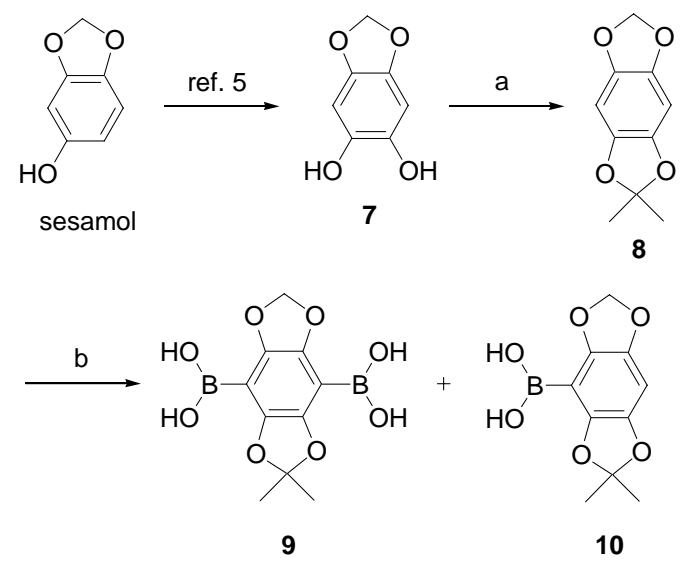

Scheme 2. Synthesis of organoboronic acids. Reagents and conditions: a) PPTS, isopropenyl methyl ether, benzene, reflux, $96 \%$, b) $n-\mathrm{BuLi}$, TMEDA, $\mathrm{B}(\mathrm{OMe})_{3}, \mathrm{THF}, \mathrm{Et}_{2} \mathrm{O},-78^{\circ} \mathrm{C}$ to rt, 9: $33 \%, \mathbf{1 0}: 24 \%$.

We tried the Suzuki-Miyaura coupling ${ }^{3}$ with diboronic acid 9 and iodobenzene (Scheme 3 ). The coupling reaction with $\mathrm{Pd}\left(\mathrm{PPh}_{3}\right)_{4}$ and $\mathrm{Na}_{2} \mathrm{CO}_{3}$ in dioxane afforded diphenyl compound 11 in one step, but the yield was low (25\%). In contrast, the cross-coupling reaction of monoboronic acid 10 with iodobenzene proceeded by the same conditions to give monophenyl compound 12 in $71 \%$ yield. Compound 12 was converted into boronic acid $\mathbf{1 3}$ by lithiation followed by treatment with $\mathrm{B}(\mathrm{OMe})_{3}$. The coupling reaction of 13 with iodobenzene was subjected to the same conditions to give diphenyl compound $\mathbf{1 1}$.
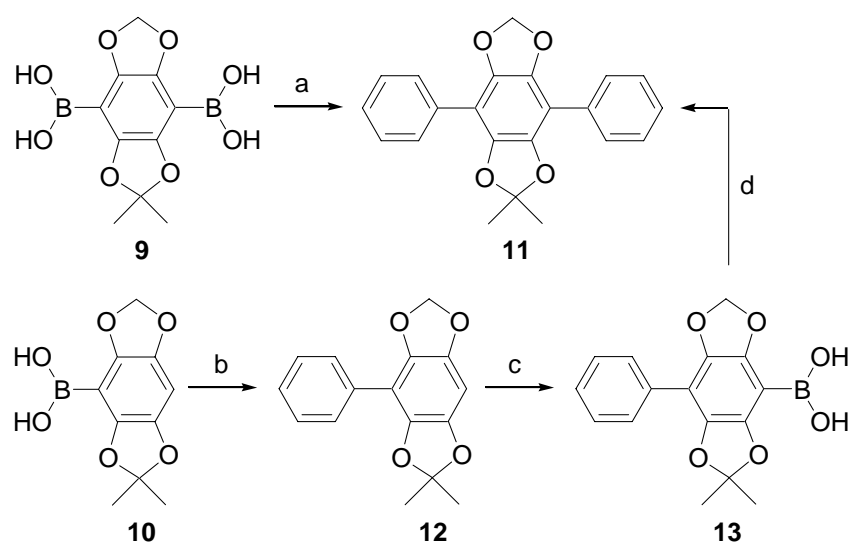

Scheme 3. Study of Suzuki-Miyaura coupling. Reagents and conditions: a) $\mathrm{PhI}, \mathrm{Pd}\left(\mathrm{PPh}_{3}\right)_{4}, \mathrm{Na}_{2} \mathrm{CO}_{3}$, dioxane, rt, 25\%; b) $\mathrm{PhI}, \mathrm{Pd}\left(\mathrm{PPh}_{3}\right)_{4}, \mathrm{Na}_{2} \mathrm{CO}_{3}$, dioxane, rt, $71 \%$; c) $n$-BuLi, TMEDA, $\mathrm{B}(\mathrm{OMe})_{3}, \mathrm{THF}, \mathrm{Et}_{2} \mathrm{O},-78{ }^{\circ} \mathrm{C}$ to rt, 49\%; d) $\mathrm{PhI}, \mathrm{Pd}\left(\mathrm{PPh}_{3}\right)_{4}, \mathrm{Na}_{2} \mathrm{CO}_{3}$, dioxane, rt, $40 \%$.
The investigation of removal of the acetonide group in $\mathbf{1 1}$ is summarized in Table 1. Acidic hydrolysis of $\mathbf{1 1}$ gave phlebiarubrone (3), an oxidative compound of catechol 14 (entry 1), which was isolated from the culture of the fungus Phlebia strigozonata. ${ }^{6}$ Synthetic phlebiarubrone (3) gave spectral data $\left({ }^{1} \mathrm{H}\right.$ NMR, ${ }^{13} \mathrm{C} \mathrm{NMR}$, and HRMS) in full agreement with those of the natural one. ${ }^{7}$ Because catechol 14 readily accepted air oxidation, 14 was not isolated. Because of the irreproducible yield, we tried to synthesize ortho-quinone 3 by selective oxidation (entries 2-5). The reaction of 11 with DDQ gave only the undesired orthoquinone 15 (entry 2). The oxidation by ammonium cerium(IV) nitrate (CAN) afforded the desired orthoquinone 3 (12\% yield) and the undesired ortho-quinone 15 (35\% yield) (entry 3 ). The reactions at low temperature increased the selectivity of ortho-quinone 3 (entries 4 and 5). However, we could not satisfy the yield and selectivity in this transformation; therefore, we next tried oxidation of protected catechol by two methylene acetal groups.

Table 1. Study of the removal of the acetonide group in $\mathbf{1 1}$.
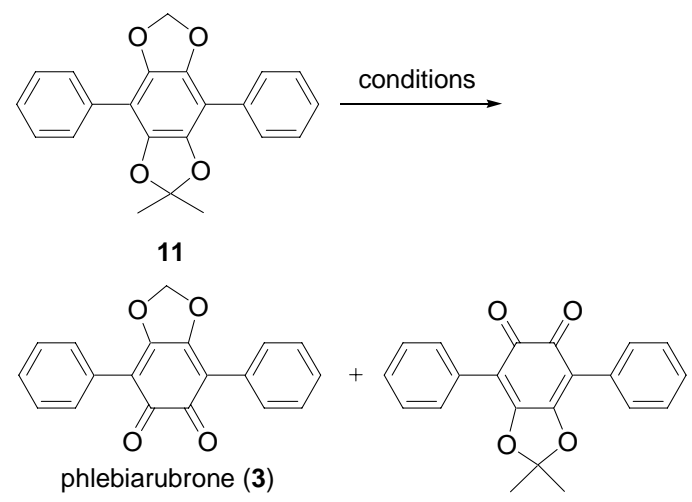

15

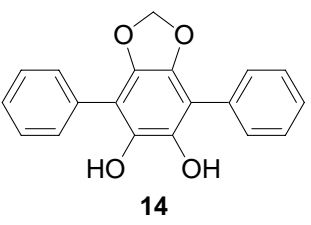

\begin{tabular}{clcccc}
\hline Entry & Conditions & $\mathbf{1 4}$ & $\mathbf{3}$ & $\mathbf{1 5}$ & $\mathbf{1 1}$ \\
\hline \multirow{2}{*}{1} & $6 \mathrm{M} \mathrm{HCl}, \mathrm{THF}-$ & $0 \%$ & $\sim 59 \%$ & $0 \%$ & $0 \%$ \\
& $\mathrm{MeOH}, 100{ }^{\circ} \mathrm{C}$ & & & & \\
2 & $\mathrm{DDQ}, \mathrm{CH}_{2} \mathrm{Cl}_{2-}-$ & - & $0 \%$ & $37 \%$ & $50 \%$ \\
& $\mathrm{H}_{2} \mathrm{O}, \mathrm{rt}, 2$ days \\
3 & $\begin{array}{l}\mathrm{CAN}, \mathrm{MeCN}-\mathrm{H}_{2} \mathrm{O}, \\
0^{\circ} \mathrm{C}, 5 \mathrm{~min} .\end{array}$ & - & $12 \%$ & $35 \%$ & $0 \%$ \\
4 & $\begin{array}{l}\mathrm{CAN}, \mathrm{MeCN}-\mathrm{H}_{2} \mathrm{O}, \\
-20{ }^{\circ} \mathrm{C}, 5 \mathrm{~min} .\end{array}$ & - & $31 \%$ & $47 \%$ & $0 \%$ \\
5 & $\begin{array}{l}\mathrm{CAN}, \mathrm{MeCN}-\mathrm{H}_{2} \mathrm{O}, \\
-40{ }^{\circ} \mathrm{C}, 10 \mathrm{~min} .\end{array}$ & - & $27 \%$ & $25 \%$ & $0 \%$ \\
\hline
\end{tabular}


The hydroxyl groups of catechol 7 were protected by the second methylene acetal (Scheme 4). ${ }^{8}$ The bis-methylene acetal 16 was converted to diboronic acid 17 by double lithiation followed by treatment with $\mathrm{B}(\mathrm{O}-\mathrm{iPr})_{3}$. Another borate reagent, $\mathrm{B}(\mathrm{OMe})_{3}$, was less effective in this case. Furthermore, the bis-methylene acetal $\mathbf{1 6}$ was converted to boronate 19 and pinacolborane 20 by sequential boronation and esterfication.
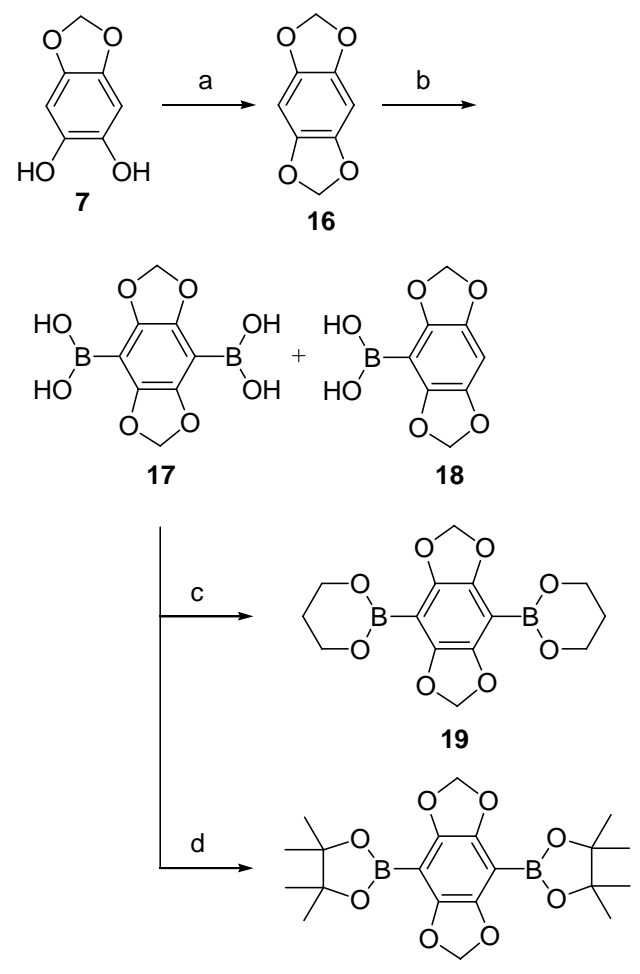

20

Scheme 4. Synthesis of boronate compounds. Reagents and conditions: a) $\mathrm{CH}_{2} \mathrm{Br}_{2}, \mathrm{Cs}_{2} \mathrm{CO}_{3}, \mathrm{DMF}, 90{ }^{\circ} \mathrm{C}, 46 \%$ (from sesamol); b) $n$-BuLi, TMEDA, $\mathrm{B}(\mathrm{O}-\mathrm{iPr})_{3}, \mathrm{Et}_{2} \mathrm{O},-78{ }^{\circ} \mathrm{C}$ to $\mathrm{rt}, 17: 55 \%, 18: 12 \%$, recovered 16: $21 \%$; c) trimethylene glycol, toluene, reflux; d) pinacol, $\mathrm{MgSO}_{4}$, $\mathrm{CH}_{2} \mathrm{Cl}_{2}$, rt.

Next, we attempted a Suzuki-Miyaura coupling, ${ }^{3}$ as depicted in Table 2. A cross-coupling reaction between diboronic acid 17 and iodobenzene with $\mathrm{Pd}\left(\mathrm{PPh}_{3}\right)_{4}$ or $\mathrm{PdCl}_{2}(\mathrm{dppf})$ afforded monophenyl compound 22 and bismethylene acetal 16 (entries 1 and 2). An attempt at a cross-coupling reaction of the diboronic acid $\mathbf{1 7}$ with $\mathrm{PdCl}_{2}\left(\mathrm{PPh}_{3}\right)_{2}$ and $\mathrm{Cs}_{2} \mathrm{CO}_{3}$ in DMF at room temperature gave the desired diphenyl compound 21, but the yield was low $(8 \%)$ (entry 3 ). The reaction at $90{ }^{\circ} \mathrm{C}$ afforded the desired diphenyl compound $\mathbf{2 1}$ in $30 \%$ yield along with monophenyl compound 22 (18\%) and bis-methylene acetal $16(4 \%)$ (entry 4). The cross-coupling reaction of the boronate 19 with $\mathrm{PdCl}_{2}\left(\mathrm{PPh}_{3}\right)_{2}$ and $\mathrm{Cs}_{2} \mathrm{CO}_{3}$ in DMF afforded the desired diphenyl compound 21 in $43 \%$ yield (entry 5). Treatment of pinacolborane 20 under the same conditions gave the desired diphenyl compound 21 in $62 \%$ yield (entry 6). In entries 5 and 6, the crude boronic esters 19 and 20 were employed, and the yields were calculated from 16 in 3 steps. Thus, this cross-coupling was the most efficiently effected by using pinacolborane 20. Also, monophenyl compound $\mathbf{2 2}$ was transformed into the desired diphenyl compound $\mathbf{2 1}$ by the same reactions (Scheme 5).

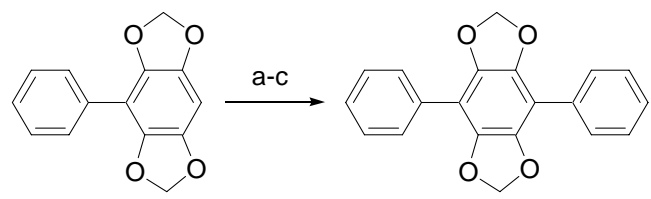

22

21

Scheme 5. Synthesis of diphenyl compound $\mathbf{2 1}$ from monophenyl compound 22. Reagents and conditions: a) n-BuLi, TMEDA, $\mathrm{B}(\mathrm{O}-\mathrm{iPr})_{3}$, $\mathrm{Et}_{2} \mathrm{O},-78{ }^{\circ} \mathrm{C}$ to $\mathrm{rt}$; b) pinacol, $\mathrm{MgSO}_{4}, \mathrm{CH}_{2} \mathrm{Cl}_{2}, \mathrm{rt}$; c) $\mathrm{PhI}, \mathrm{PdCl}_{2}\left(\mathrm{PPh}_{3}\right)_{2}$, $\mathrm{Cs}_{2} \mathrm{CO}_{3}$, DMF, $90{ }^{\circ} \mathrm{C}, 27 \%$ in 3 steps, (recovered 16: 27\%).

Since the diphenyl compound $\mathbf{2 1}$ has been synthesized in an available yield, we attempted oxidation of 21. Oxidation of 21 with CAN gave phlebiarubrone (3) in quantitative yield (Scheme 6). To convert phlebiarubrone (3) to ustalic acid dimethyl ester (2), we followed the procedure reported by Nishikawa et al. ${ }^{2}$ with a modification. Phlebiarubrone (3) was treated with $\mathrm{Pb}(\mathrm{OAc})_{4}$ (20 equiv) in $\mathrm{MeOH}$ and toluene in the presence of $\mathrm{K}_{2} \mathrm{CO}_{3}$ (2.1 equiv) to give ustalic acid dimethyl ester (2). This modification increased the yield of the ustalic acid dimethyl ester (2) to $11 \%$. Hydrolysis of the ustalic acid dimethyl ester (2) with $3 \mathrm{M} \mathrm{KOH}$ aq. in DMSO at room temperature for 1 day afforded the ustalic acid monomethyl ester (23). The monomethyl ester $\mathbf{2 3}$ was treated under the same conditions for 4 days to give ustalic acid (1) in 38\% yield. The reaction at $70{ }^{\circ} \mathrm{C}$ for $39 \mathrm{~h}$ gave ustalic acid (1) in $23 \%$ yield. Synthetic ustalic acid (1) gave spectral data $\left({ }^{1} \mathrm{H}\right.$ NMR, ${ }^{13} \mathrm{C}$ NMR, IR, and HRMS) in full agreement with those of the natural one, ${ }^{1}$ thus completing the total synthesis.
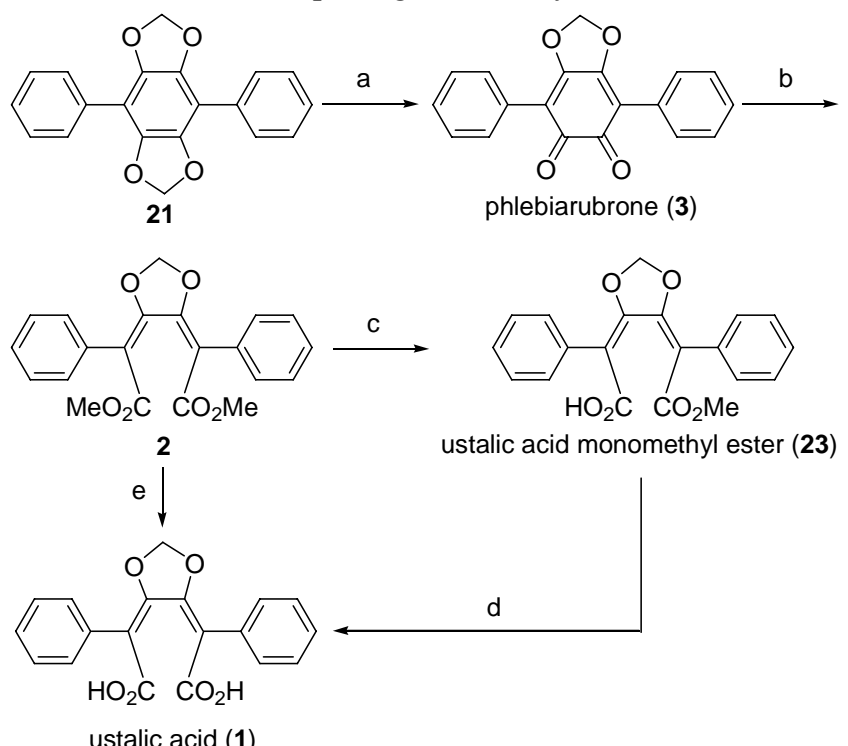

Scheme 6. Synthesis of ustalic acid (1). Reagents and conditions: a) $\mathrm{CAN}, \mathrm{MeCN}-\mathrm{H}_{2} \mathrm{O}, 0^{\circ} \mathrm{C}$, quant.; b) $\mathrm{Pb}(\mathrm{OAc})_{4}, \mathrm{~K}_{2} \mathrm{CO}_{3}$, toluene, $\mathrm{MeOH}$, rt, $11 \%$; c) $3 \mathrm{M} \mathrm{KOH}$ aq., DMSO, rt; d) $3 \mathrm{M} \mathrm{KOH}$ aq., DMSO, rt, 38\% in 2 steps; e) $3 \mathrm{M} \mathrm{KOH}$ aq., DMSO, $70{ }^{\circ} \mathrm{C}, 23 \%$. 
Table 2. Study of Suzuki-Miyaura coupling.

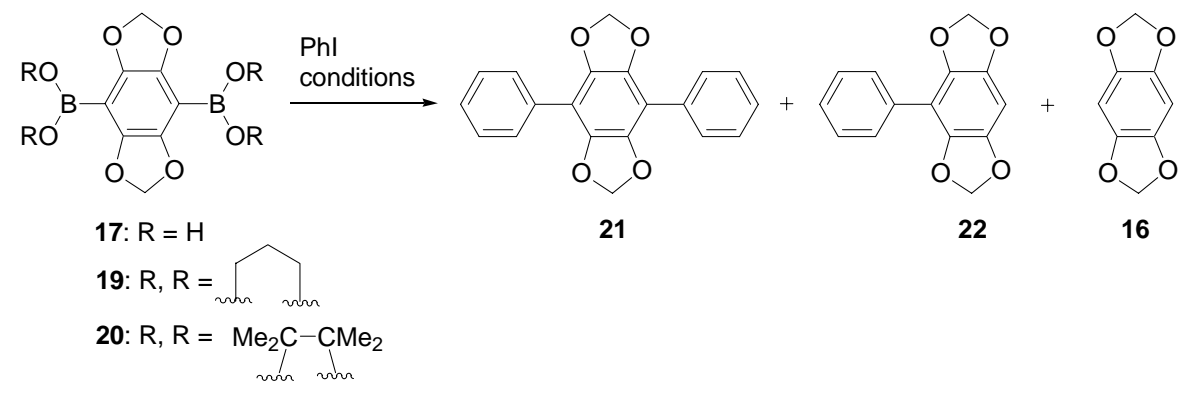

\begin{tabular}{|c|c|c|c|c|c|c|c|c|}
\hline \multirow[b]{2}{*}{ Entry } & \multirow[b]{2}{*}{ Substrate } & \multicolumn{4}{|c|}{ Conditions } & \multicolumn{3}{|c|}{ Yield } \\
\hline & & Catalyst & Solvent & Base & Temp. & 21 & 22 & 16 \\
\hline 1 & 17 & $\mathrm{Pd}\left(\mathrm{PPh}_{3}\right)_{4}$ & 1,4-dioxane & $\mathrm{Na}_{2} \mathrm{CO}_{3} a q$ & $\mathrm{rt}$ & $0 \%$ & $16 \%$ & $31 \%$ \\
\hline 2 & 17 & $\mathrm{PdCl}_{2}(\mathrm{dppf})$ & DME & $\mathrm{K}_{3} \mathrm{PO}_{4} a q$ & $60{ }^{\circ} \mathrm{C}$ & $0 \%$ & $43 \%$ & $8 \%$ \\
\hline 3 & 17 & $\mathrm{PdCl}_{2}\left(\mathrm{PPh}_{3}\right)_{2}$ & DMF & $\mathrm{Cs}_{2} \mathrm{CO}_{3} a q$ & $\mathrm{rt}$ & $8 \%$ & $13 \%$ & $11 \%$ \\
\hline 4 & 17 & $\mathrm{PdCl}_{2}\left(\mathrm{PPh}_{3}\right)_{2}$ & DMF & $\mathrm{Cs}_{2} \mathrm{CO}_{3} a q$ & $90^{\circ} \mathrm{C}$ & $30 \%$ & $18 \%$ & $4 \%$ \\
\hline $5^{*}$ & 19 & $\mathrm{PdCl}_{2}\left(\mathrm{PPh}_{3}\right)_{2}$ & DMF & $\mathrm{Cs}_{2} \mathrm{CO}_{3}$ & $\mathrm{rt}$ & $43 \%$ & $16 \%$ & $32 \%$ \\
\hline $6^{*}$ & 20 & $\mathrm{PdCl}_{2}\left(\mathrm{PPh}_{3}\right)_{2}$ & DMF & $\mathrm{Cs}_{2} \mathrm{CO}_{3}$ & $90{ }^{\circ} \mathrm{C}$ & $62 \%$ & $3.2 \%$ & $0 \%$ \\
\hline
\end{tabular}

* Isolated yields calculated from 16 (in 3 steps).

\section{Conclusion}

In summary, we achieved the first synthesis of ustalic acid (1) by using the Suzuki-Miyaura coupling as a key step. Further structure-activity relationship studies are now in progress.

\section{Experimental}

\subsection{General methods.}

${ }^{1} \mathrm{H}$ NMR spectra were recorded on a JEOL JNM-EX270 $(270 \mathrm{MHz})$, or a Bruker AVANCE $500(500 \mathrm{MHz})$ spectrometer. Chemical shifts for ${ }^{1} \mathrm{H}$ NMR are reported in parts per million (ppm) downfield from tetramethylsilane as the internal standard, and coupling constants are in hertz $(\mathrm{Hz})$. The following abbreviations are used for spin multiplicity: $\mathrm{s}=$ singlet, $\mathrm{d}=$ doublet, $\mathrm{t}=$ triplet, $\mathrm{q}=$ quartet, $\mathrm{m}=$ multiplet, and $\mathrm{br}=$ broad. ${ }^{13} \mathrm{C}$ NMR spectra were recorded on a JEOL JNM-EX270 (67.8 MHz), or a Bruker AVANCE $500(125 \mathrm{MHz})$ spectrometer. Chemical shifts for ${ }^{13} \mathrm{C}$ NMR are reported in ppm, relative to the central line of a triplet at $77.0 \mathrm{ppm}$ for deuteriochloroform. IR spectra were recorded on a JASCO FT/IR-300 instrument and are reported in wavenumbers $\left(\mathrm{cm}^{-1}\right)$. ESI mass spectra were recorded on a Applied Biosystems QStar/Pulsar $i$ spectrometer. Elemental analyses were recorded on a Yanaco CHN CORDER MT-6. TLC analysis were conducted on E. Merck precoated silica gel $60 \mathrm{~F}_{254}(0.25$ $\mathrm{mm}$ layer thickness). Fuji Silysia silica gel BW-820 MH was used for column chromatography unless otherwise noted. Organic solvents for moisture-sensitive reactions were distilled from the following drying agents: THF, $\mathrm{Et}_{2} \mathrm{O}$, DME, and 1,4-dioxane (Na-benzophenone ketyl), benzene and toluene (Na). Anhydrous acetone, $\mathrm{MeOH}, \mathrm{CH}_{2} \mathrm{Cl}_{2}$ and DMF were purchased from Kanto Chemical Co., Inc., or Wako Pure Chemical Industries, Ltd., and used without further drying. All moisture-sensitive reactions were performed under an atmosphere of argon or nitrogen, and the starting materials were azeotropically dried with benzene before use. All new compounds were determined to be $>95 \%$ pure by ${ }^{1} \mathrm{H}$ NMR unless otherwise noted.

\subsection{Bis-methylene acetal 16.}

To a stirred solution of catechol 7 (1.02 g, $6.62 \mathrm{mmol})$ and $\mathrm{Cs}_{2} \mathrm{CO}_{3}(2.67 \mathrm{~g}, 8.19 \mathrm{mmol})$ in DMF $(10 \mathrm{~mL})$ was added $\mathrm{CH}_{2} \mathrm{Br}_{2}(0.71 \mathrm{~mL}, 9.93 \mathrm{mmol})$ at room temperature, and the mixture was stirred at $90{ }^{\circ} \mathrm{C}$ for $19 \mathrm{~h}$. After cooling to room temperature, the mixture was diluted with $\mathrm{Et}_{2} \mathrm{O}(30$ $\mathrm{mL}$ ), filtrated with Celite, and this Celite was rinsed with $\mathrm{Et}_{2} \mathrm{O}(3 \times 6 \mathrm{~mL})$. The filtrate and rinse were washed with 
$\mathrm{H}_{2} \mathrm{O}(3 \times 10 \mathrm{~mL})$, and the aqueous layer was extracted with $\mathrm{Et}_{2} \mathrm{O}(3 \times 6 \mathrm{~mL})$. The combined organic layers were washed with $1 \mathrm{M} \mathrm{NaOH}$ aq. $(\times 3), \mathrm{H}_{2} \mathrm{O}(\times 2)$, and brine $(\times 1)$; dried $\left(\mathrm{Na}_{2} \mathrm{SO}_{4}\right)$; and concentrated. The residual oil was purified by column chromatography on silica gel (15 g, $n$-hexaneEtOAc $30: 1 \rightarrow 10: 1)$ to give bis-methylene acetal 16 (489 $\mathrm{mg}, 46 \%$.) as a white solid: colorless crystals; Mp 139$140{ }^{\circ} \mathrm{C}\left(n\right.$-hexane- $\left.\mathrm{CH}_{2} \mathrm{Cl}_{2}\right) ;{ }^{1} \mathrm{H}$ NMR $\left(270 \mathrm{MHz}, \mathrm{CDCl}_{3}\right) \delta$ $6.48(\mathrm{~s}, 2 \mathrm{H}), 5.86(\mathrm{~s}, 4 \mathrm{H}) ;{ }^{13} \mathrm{C} \mathrm{NMR}\left(67.8 \mathrm{MHz}, \mathrm{CDCl}_{3}\right) \delta$ 141.1, 101.0, 93.0; Anal.Calcd. for $\mathrm{C}_{8} \mathrm{H}_{6} \mathrm{O}_{4}$ : C, 57.84; $\mathrm{H}$, 3.64; O, 38.52\%. Found: C, 57.76; H, 3.76; O, 38.57\%.

\subsection{Diphenyl compound 21.}

To a stirred solution of bis-methylene acetal 16 (400 mg, $2.41 \mathrm{mmol})$ in $\mathrm{Et}_{2} \mathrm{O}(10 \mathrm{~mL})$ at $0{ }^{\circ} \mathrm{C}$ were added TMEDA $(1.0 \mathrm{~mL}, 6.71 \mathrm{mmol})$ and $n$-BuLi $(1.61 \mathrm{M}$ solution in $n$ hexane, $4.5 \mathrm{~mL}, 7.25 \mathrm{mmol}$ ) under nitrogen flow, and the resultant mixture was stirred at $0{ }^{\circ} \mathrm{C}$ for $30 \mathrm{~min}$. After cooling to $-78{ }^{\circ} \mathrm{C}, \mathrm{B}(\mathrm{O}-\mathrm{iPr})_{3}(2.8 \mathrm{~mL}, 12.2 \mathrm{mmol})$ in $\mathrm{Et}_{2} \mathrm{O}$ $(4.2 \mathrm{~mL})$ was added, and the resultant mixture was stirred at $-78{ }^{\circ} \mathrm{C}$ for $1 \mathrm{~h}$. The mixture was stirred at room temperature for $17 \mathrm{~h}$, diluted with $1 \mathrm{M} \mathrm{HCl}$ to $\mathrm{pH} 1$, and extracted with $\mathrm{CHCl}_{3}(4 \times 15 \mathrm{~mL})$. The combined extracts were dried $\left(\mathrm{Na}_{2} \mathrm{SO}_{4}\right)$ and concentrated to afford crude diboronic acid 17 (670 $\mathrm{mg})$, which was used for the next reaction without further purification.

The crude diboronic acid 17 (670 mg), pinacol (2.26 g, $19.1 \mathrm{mmol})$, and $\mathrm{MgSO}_{4}(1.30 \mathrm{~g}, 10.8 \mathrm{mmol})$ were dissolved in $\mathrm{CH}_{2} \mathrm{Cl}_{2}(16 \mathrm{~mL})$, and the resultant mixture was stirred at room temperature for $17.5 \mathrm{~h}$. The mixture was filtrated with Celite, and this Celite was rinsed with $\mathrm{CH}_{2} \mathrm{Cl}_{2}$ $(3 \times 5 \mathrm{~mL})$. The filtrate and rinse were combined and concentrated to afford crude diboronic pinacol ester 20 $(1.28 \mathrm{~g})$, which was used for the next reaction without further purification.

All solvents were degassed by freeze-thawing. To a stirred solution of crude diboronic pinacol ester $20(1.28 \mathrm{~g})$ and iodobenzene $(0.8 \mathrm{~mL}, 7.18 \mathrm{mmol})$ in DMF $(10 \mathrm{~mL})$ were added $\mathrm{PdCl}_{2}\left(\mathrm{PPh}_{3}\right)_{2}(190 \mathrm{mg}, 0.24 \mathrm{mmol})$ and $\mathrm{Cs}_{2} \mathrm{CO}_{3}$ $(2.34 \mathrm{~g}, 7.18 \mathrm{mmol})$ at room temperature in a glove box. The mixture was stirred at $90{ }^{\circ} \mathrm{C}$ for $14 \mathrm{~h}$ under nitrogen flow and diluted with $\mathrm{H}_{2} \mathrm{O}(10 \mathrm{~mL})$ at room temperature. The resultant mixture was filtrated with Celite, and this Celite was rinsed with $\mathrm{Et}_{2} \mathrm{O}(3 \times 10 \mathrm{~mL})$. The layers were separated, and the aqueous layer was extracted with $\mathrm{Et}_{2} \mathrm{O}$ $(3 \times 15 \mathrm{~mL})$. The combined $\mathrm{Et}_{2} \mathrm{O}$ layers were washed with 1 $\mathrm{M} \mathrm{HCl}(\times 2), \mathrm{H}_{2} \mathrm{O}(\times 1)$, and brine $(\times 1)$; dried $\left(\mathrm{Na}_{2} \mathrm{SO}_{4}\right)$; and concentrated. The residual solid was purified by recrystallization from $n$-hexane- $\mathrm{CH}_{2} \mathrm{Cl}_{2}$ to give diphenyl compound 21 (451 mg, 59\% in 3 steps) as colorless crystals. The mother liquid was concentrated, and the residual solid was purified by recycle HPLC [JAIGEL-1H-40 $(600 \times 20$ $\mathrm{mm})$ and JAIGEL-2H-40 $(600 \times 20 \mathrm{~mm})$; flow rate 3.8 $\mathrm{mL} / \mathrm{min}$; detection, UV $254 \mathrm{~nm}$; solvent $\mathrm{CHCl}_{3}$ ] to give diphenyl compound 21 ( $21.7 \mathrm{mg}, 2.8 \%$ in 3 steps; total 473 $\mathrm{mg}, 62 \%$ in 3 steps) and monophenyl compound 22 (18.7 $\mathrm{mg}, 3.2 \%$ in 3 steps) as colorless crystals, respectively: Diphenyl compound 21: Mp 204-205 ${ }^{\circ} \mathrm{C}$ (n-hexane$\left.\mathrm{CH}_{2} \mathrm{Cl}_{2}\right) ;{ }^{1} \mathrm{H} \mathrm{NMR}\left(270 \mathrm{MHz}, \mathrm{CDCl}_{3}\right) \delta$ 7.82-7.86 (m, $\left.4 \mathrm{H}\right)$, 7.42-7.48 (m, 4H), 7.31-7.37 (m, 2H), $6.00(\mathrm{~s}, 4 \mathrm{H}) ;{ }^{13} \mathrm{C}$ NMR $\left(67.8 \mathrm{MHz}, \mathrm{CDCl}_{3}\right) \delta 139.0,131.2,128.8,128.2$, 127.8, 107.8, 100.8; Anal.Calcd. for $\mathrm{C}_{20} \mathrm{H}_{14} \mathrm{O}_{4}$ : C, 75.46; H, 4.43; O, 20.10\%. Found: C, 75.19; H, 4.57; O, 20.24\%; Monophenyl compound 22: Mp 138-139 ${ }^{\circ} \mathrm{C}$ (n-hexane$\left.\mathrm{CH}_{2} \mathrm{Cl}_{2}\right) ;{ }^{1} \mathrm{H}$ NMR $\left(270 \mathrm{MHz}, \mathrm{CDCl}_{3}\right) \delta 7.78-7.83(\mathrm{~m}, 2 \mathrm{H})$, 7.41-7.47 (m, 2H), 7.31-7.37 (m, 1H), $6.49(\mathrm{~s}, 1 \mathrm{H}), 5.93(\mathrm{~s}$, $4 \mathrm{H}) ;{ }^{13} \mathrm{C}$ NMR $\left(67.8 \mathrm{MHz}, \mathrm{CDCl}_{3}\right) \delta 141.4,138.7,131.2$, 128.7, 128.2, 127.8, 108.9, 101.0, 92.1; Anal.Calcd. for $\mathrm{C}_{14} \mathrm{H}_{10} \mathrm{O}_{4}$ : C, 69.42; H, 4.16; O, 26.42\%. Found: C, 69.25; $\mathrm{H}, 4.26$; O, 26.49\%.

\section{4 phlebiarubrone (3).}

To a stirred solution of diphenyl compound 21 (410 mg, $1.28 \mathrm{mmol})$ in acetonitrile $(97 \mathrm{~mL})$ was added CAN $(1.0 \mathrm{M}$ solution in $\left.\mathrm{H}_{2} \mathrm{O}, 3.9 \mathrm{~mL}, 3.90 \mathrm{mmol}\right)$ at $0{ }^{\circ} \mathrm{C}$, and the mixture was stirred at $0{ }^{\circ} \mathrm{C}$ for $3 \mathrm{~min}$. The mixture was diluted with $\mathrm{H}_{2} \mathrm{O}(80 \mathrm{~mL})$ and extracted with $\mathrm{CHCl}_{3}(3 \times 15$ $\mathrm{mL})$. The combined extracts were dried $\left(\mathrm{Na}_{2} \mathrm{SO}_{4}\right)$ and concentrated. The residual oil was purified by column chromatography on silica gel (10 g, n-hexane-EtOAc $10: 1 \rightarrow 4: 1)$ to give red solid. The red solid was purified by recrystallization from $n$-hexane $-\mathrm{CH}_{2} \mathrm{Cl}_{2}$ to give phlebiarubrone (3) (389 mg, quant.) as red crystals: $\mathrm{Mp}$ 248-250 ${ }^{\circ} \mathrm{C}$ (n-hexane- $\left.\mathrm{CH}_{2} \mathrm{Cl}_{2}\right) ;{ }^{1} \mathrm{H}$ NMR $(270 \mathrm{MHz}$, $\left.\mathrm{CDCl}_{3}\right) \delta 7.60-7.65(\mathrm{~m}, 4 \mathrm{H}), 7.34-7.48(\mathrm{~m}, 6 \mathrm{H}), 6.13(\mathrm{~s}$, $2 \mathrm{H}) ;{ }^{13} \mathrm{C} \mathrm{NMR}\left(67.8 \mathrm{MHz}, \mathrm{CDCl}_{3}\right) \delta 175.9,156.1,129.4$, 128.7, 128.6, 128.1, 113.7, 102.7; HRESIMS m/z 327.0636, calcd for $\mathrm{C}_{19} \mathrm{H}_{12} \mathrm{NaO}_{4}[\mathrm{M}+\mathrm{Na}]^{+} 327.0633$.

\section{5 ustalic acid dimethyl ester (2).}

Phlebiarubrone (3) (100 mg, $0.329 \mathrm{mmol}), \mathrm{Pb}(\mathrm{OAc})_{4}$ (2.92 g, $6.59 \mathrm{mmol})$, and $\mathrm{K}_{2} \mathrm{CO}_{3}(96.2 \mathrm{mg}, 0.696 \mathrm{mmol})$ were dissolved in toluene $(8.2 \mathrm{~mL})$ and $\mathrm{MeOH}(5.8 \mathrm{~mL})$. The resultant mixture was stirred at room temperature for $47 \mathrm{~h}$, diluted with $\mathrm{H}_{2} \mathrm{O}(15 \mathrm{~mL}$ ) and ethylene glycol (a few drops), and filtrated with Celite. The filtrate was extracted with $\mathrm{Et}_{2} \mathrm{O}(4 \times 15 \mathrm{~mL})$. The combined extracts were washed with $\mathrm{H}_{2} \mathrm{O}$, saturated aqueous $\mathrm{NaHCO}_{3}$, and $\mathrm{H}_{2} \mathrm{O}$; dried $\left(\mathrm{Na}_{2} \mathrm{SO}_{4}\right)$; and concentrated. The residual oil was purified by column chromatography on silica gel $(8.0 \mathrm{~g}, n$-hexaneEtOAc 5:1 $\rightarrow 2: 1)$, preparative TLC $\left(\mathrm{CH}_{2} \mathrm{Cl}_{2}\right)$, and preparative TLC ( $n$-hexane-EtOAc 2:1) to give ustalic acid dimethyl ester (2) (13 mg, 11\%) as a yellow solid: IR (film) $1718,1637 \mathrm{~cm}^{-1} ;{ }^{1} \mathrm{H}$ NMR $\left(270 \mathrm{MHz}, \mathrm{CDCl}_{3}\right) \delta 7.31-7.42$ $(\mathrm{m}, 10 \mathrm{H}), 5.41(\mathrm{~s}, 2 \mathrm{H}), 3.73(\mathrm{~s}, 6 \mathrm{H}) ;{ }^{13} \mathrm{C} \mathrm{NMR}(67.8 \mathrm{MHz}$, $\left.\mathrm{CDCl}_{3}\right) \delta 167.5,148.6,134.4,129.8,127.9,127.8,115.2$, 
95.9, 52.2; HRESIMS m/z 389.0998, calcd for $\mathrm{C}_{21} \mathrm{H}_{18} \mathrm{NaO}_{6}$ $[\mathrm{M}+\mathrm{Na}]^{+} 389.1001$.

\section{6 ustalic acid (1).}

The ustalic acid dimethyl ester (2) $(2.6 \mathrm{mg}, 7.10 \mu \mathrm{mol})$ was treated with $3 \mathrm{M} \mathrm{KOH}$ aq.-DMSO $(1: 1,0.45 \mathrm{~mL})$ at room temperature for $24 \mathrm{~h}$. The mixture was diluted with saturated $\mathrm{NaH}_{2} \mathrm{PO}_{4}$ to $\mathrm{pH} 3$ and extracted with $\mathrm{CHCl}_{3}(\times 4)$. The combined extracts were dried $\left(\mathrm{Na}_{2} \mathrm{SO}_{4}\right)$ and concentrated to afford crude ustalic acid monomethyl ester (23) $(2.3 \mathrm{mg})$, which was used for the next reaction without further purification.

The crude ustalic acid monomethyl ester (23) (2.3 mg) was treated with $3 \mathrm{M} \mathrm{KOH}$ aq.-DMSO $(1: 1,0.45 \mathrm{~mL})$ at room temperature for 4 days. The mixture was diluted with saturated $\mathrm{NaH}_{2} \mathrm{PO}_{4}$ to $\mathrm{pH} 3$ and extracted with $\mathrm{CHCl}_{3}(\times 4)$. The combined extracts were dried $\left(\mathrm{Na}_{2} \mathrm{SO}_{4}\right)$ and concentrated to afford crude ustalic acid (1). The residual oil was purified by HPLC (Develosil ODS-HG-5 $(250 \times 20$ $\mathrm{mm}$ ), flow rate $5 \mathrm{~mL} / \mathrm{min}$; detection, UV $254 \mathrm{~nm}$; solvent $50 \% \mathrm{MeOH} / 0.1 \% \mathrm{TFA})$ to give ustalic acid (1) $(0.9 \mathrm{mg}$, $38 \%$, retention time $91.2 \mathrm{~min}$ ) as a white solid: IR (film) $1698,1630 \mathrm{~cm}^{-1} ;{ }^{1} \mathrm{H}$ NMR $\left(270 \mathrm{MHz}, \mathrm{CDCl}_{3}\right) \delta$ 7.29-7.41 $(\mathrm{m}, 10 \mathrm{H}), 5.46(\mathrm{~s}, 2 \mathrm{H}) ;{ }^{13} \mathrm{C}$ NMR $\left(67.8 \mathrm{MHz}, \mathrm{CDCl}_{3}\right) \delta$ 174.2, 149.2, 133.4, 129.9, 128.2, 127.9, 115.0, 96.3; HRESIMS m/z 361.0686, calcd for $\mathrm{C}_{19} \mathrm{H}_{14} \mathrm{NaO}_{6}[\mathrm{M}+\mathrm{Na}]^{+}$ 361.0688 .

\section{Acknowledgments}

This work was supported in part by Grants-in-Aid for Scientific Research on Priority Area (No. 16073204, "'Creation of Biologically Functional Molecules'); and by the 21st COE program from the Ministry of Education, Culture, Sports, Science and Technology (MEXT), Japan. We would like to thank Mr. Ikuo Iida (University of Tsukuba) for the elemental analyses.

\section{References}

1. Sano, Y.; Sayama, K.; Arimoto, Y.; Inakuma, T.; Kobayashi, K.; Koshino, H.; Kawagishi, H. Chem. Commun. 2002, 1384 1385 .

2. Sawayama, Y.; Tsujimoto, T.; Sugino, K.; Nishikawa, T.; Isobe, M.; Kawagishi, H. Biosci. Biotechnol. Biochem. 2006, 70, 2998-3003.

3. Miyaura, N.; Suzuki, A. Chem. Rev. 1995, 95, 2457-2483.

4. Ye, Y. Q.; Koshino, H.; Onose, J.; Yoshikawa, K.; Abe, N.; Takahashi, S. Org. Lett. 2007, 9, 4131-4134.
5. Hussain, H. H.; Babic, G.; Durst, T.; Wright, J. S.; Flueraru, M.; Chichirau, A.; Chepelev, L. L. J. Org. Chem. 2003, 68, $7023-7032$.

6. (a) McMorris, T. C.; Anchel, M. Tetrahedron Lett. 1963, 335-337; (b) McMorris, T. C.; Anchel, M. Tetrahedron 1967, 23, 3985-3991.

7. Jokela, R.; Lounasmaa, M. Plant Med. 1997, 63, 381-383.

8. Dallacker, F.; Edelmann, W.; Weiner, A. Liebigs Ann. Chem. 1968, 719, 112-118. 